\title{
KESESUAIAN LAHAN DAN PRODUKTIVITAS UBI CILEMBU SEBAGAI KOMODITAS UNGGULAN DI KABUPATEN SUMEDANG
}

\section{(Land Suitability and Cilembu Sweet Potato as A Superior Commodity in Sumedang District)}

\author{
Mujiono $^{1}$ dan Kurniawati Sugiyo ${ }^{2}$ \\ ${ }^{1}$ Prodi Agribisnis Faperta Univ. Dehasen Bengkulu \\ ${ }^{2}$ Kementerian Agraria, Tata Ruang dan Badan Pertanahan Nasional RI \\ *Email Koresponden : mujiono@unived.ac.id
}

Article Submitted : 13-08-2019

Article Accepted : :05-10-2019

\begin{abstract}
This study aimed to determine the suitability of Cilembu sweet potato land. Land suitability assessment in this study was carried out by a method of matching between crop productivity and land characteristics as parameters with land suitability class criteria that have been prepared based on usage requirements or growing requirements of plants or other commodities evaluated. The results showed that $33 \%$ of the area in Sumedang district was physically very suitable for planting Cilembu sweet potato which covers the area of origin of Cilembu sweet potato as well as the surrounding area and areas in the north of the district. High yam productivity is found in the west of the district, including the area of origin of Cilembu sweet potatoes and their surroundings. The relationship of land suitability between Cilembu yam and productivity of Cilembu yam is shown by the alignment areas that are in harmony, (-), not suitable $(+)$ and not suitable. The alignment areas that need attention are the aligned (-) and non-aligned $(+)$ regions.
\end{abstract}

Keywords : Cilembu sweet potato, land suitablility, productivity

\section{PENDAHULUAN}

Ubi jalar (Ipomoea batatas) merupakan salah satu komoditas yang cukup bagus sebagai usaha pertanian palawija, sebab mempunyai potensi untuk terus dikembangkan baik sebagai bahan pangan, pakan maupun bahan industri. Kuantitas produksi ubi jalar di Indonesia cukup melimpah dan dapat diatur karena tanaman ini hidup tergantung pada musim (Ruwanti, 2010). Ada banyak jenis ubi jalar yang tumbuh dan diusahakan serta menjadi komoditas tanaman pangan di Indonesia, salah satunya adalah varietas Cilembu. Ubi Cilembu merupakan tanaman pangan asli dari kab. Sumedang dan menjadi salah satu produk pertanian unggulan. Peranan usahatani ubi cilembu memiliki prospek yang baik sebagai komoditas pertanian unggulan tanaman palawija. Menurut Haryati, dkk (2015) ubi cilembu juga merupakan tanaman ubi yang paling produktif dan banyak diminati konsumen sehingga sangat prospektif untuk meningkatkan pendapatan petani. Dari sisi ekonomis, ubi Cilembu mempunyai nilai jual yang tinggi dan mampu menembus pasar regional dan menjadi salah satu penghasil devisa bagi negara melalui ekspor. Tujuan utama ekspor ubi Cilembu adalah ke Jepang, Korea, Singapura, 
Malaysia bahkan Timur Tengah (Solihin, 2014). Pengembangan komoditas unggulan ubi Cilembu tengah menghadapi penurunan jumlah produksi (Solihin, 2007). Berdasarkan data BPS Jabar (2014), produksi ubi jalar (termasuk varietas ubi Cilembu) di kabupaten Sumedang mengalami peningkatan dari tahun 2008 sampai dengan tahun 2012 dan terdapat penurunan pada tahun 2013.

Penurunan produksi disebabkan lahan yang mempunyai karakteristik yang sesuai dengan persyaratan tumbuh ubi Cilembu di kabupaten Sumedang terbatas dan mulai dialihfungsikan menjadi penggunaan lahan non pertanian (Solihin, 2007). Penggunaan lahan tersebut cenderung irreversible, sehingga tidak mungkin mendapatkan kembali karakteristik lahan yang sesuai dengan persyaratan tumbuh optimal ubi Cilembu seperti semula. Semula lahan pertanian desa Cilembu yang memungkinkan ditanami ubi jalar adalah seluas 292,16 hektar yang terdiri dari 192 hektar sawah dan 100,16 lahan kering, tetapi sekarang luas tersebut sudah berkurang.

Demi mempertahankan keberlanjutan ubi Cilembu dan potensi pasarnya yang potensial, perlu adanya upaya untuk mencari alternatif lahan yang sesuai dengan kondisi dan karakteristik yang sesuai dengan persyaratan tumbuh tanaman ubi jalar varietas Cilembu. Mengacu kepada persyaratan kesesuaian lahan ubi Cilembu, perlu dilakukan penelitian pemetaan lahan yang dapat melihat distribusi potensi pengembangan ubi Cilembu.

Penelitian ini ditujukan untuk mengetahui distribusi secara spasial lahan serta alternatif lahan yang mempunyai potensi bagi pengembangan ubi Cilembu di kabupaten Sumedang. Produktivitas tanaman digunakan untuk mengevaluasi kesesuaian lahan tersebut.

Dari segi ilmiah, hasil penelitian diharapkan dapat menjadi pertimbangan bagi penelitian-penelitian lain yang terkait dengan ubi Cilembu dan lahan yang dapat dikembangkan bagi ubi Cilembu. Sementara dari segi praktis, hasil penelitian ini diharapkan dapat memberikan gambaran baik bagi pemerintah daerah maupun pihak-pihat terkait yang berminat untuk mengembangkan potensi ubi Cilembu sebagai komoditas unggulan di kabupaten Sumedang.

\section{METODE PENELITIAN}

Lokasi penelitian adalah kabupaten Sumedang yang merupakan daerah asal ubi jalar varietas Cilembu. Sumedang berbatasan langsung dengan 5 kabupaten di Jawa Barat lainnya. Kabupaten ini terdiri atas 26 kecamatan dengan 276 desa dan 7 kelurahan.

Kesesuaian lahan adalah kecocokan suatu lahan untuk penggunaan tertentu. Biasanya berdasarkan pada sifat lingkungan fisiknya; iklim, tanah, topografi, hidrologi dan atau drainase sesuai untuk usahatani atau komoditas tertentu yang produktif (Djaenudin et al., 1993 dalam Wijanarko, 2007). Penilaian kesesuaian lahan dilakukan dengan metode pencocokkan (matching) antara produktivitas tanaman dan karakteristik lahan sebagai parameter dengan kriteria kelas kesesuaian lahan yang telah disusun berdasarkan persyaratan penggunaan atau persyaratan tumbuh tanaman atau komoditas lainnya yang dievaluasi. Prasyarat lahan/karakteristik lahan untuk tanaman ubi Cilembu disajikan dalam Tabel 1. Klasifikasi kesesuaian lahan menggunakan Struktur Klasifikasi Lahan yang dibuat oleh FAO (1976) dalam Permentan Nomor 79 Tahun 
2013 tentang Pedoman Kesesuaian Lahan pada Komoditas Tanaman Pangan.

Klasifikasi yang digunakan sampai pada tingkat kelas yaitu lahan sangat sesuai (S1), cukup sesuai (S2), sesuai marginal (S3) dan tidak sesuai $(\mathrm{N})$. Kelas klasifikasi lahan dapat dilihat pada Tabel 2. Variabel yang digunakan dalam penelitian ini adalah variabel untuk mendapatkan kesesuaian lahan tanaman ubi Cilembu dan produktivitas tanaman ubi Cilembu. Variabel untuk menentukan kesesuaian lahan ubi Cilembu mengacu kepada karakteristik fisik untuk persyaratan tumbuhnya, yaitu suhu, curah hujan, lama bulan kering, drainase, tekstur tanah, kedalaman tanah, $\mathrm{pH}$ air, lereng dan genangan.

Tabel 1. Prasyarat Karakteristik Lahan Tanaman Ubi Cilembu

\begin{tabular}{|c|c|c|c|}
\hline & \multirow{2}{*}{$\begin{array}{l}\text { Prasyarat Renggunaan/ } \\
\text { KarakteristikLahan } \\
\end{array}$} & \multicolumn{2}{|r|}{ Kelas Keses } \\
\hline & & S1 & S2 \\
\hline & Sphp (tc) & & \\
\hline & Suhu tahunan rata-rata $\left({ }^{\circ} \mathrm{C}\right)$ & $\begin{array}{c}22-25 \\
22,4-23 *\end{array}$ & $\begin{array}{l}25-30 \\
20-22\end{array}$ \\
\hline & Ketersediaan air (घа) & & \\
\hline & Curah hujan (mm) & $800-1.500$ & $\begin{array}{c}600-800 \\
1.500-2.500\end{array}$ \\
\hline & Lama bulan kering (bln) & $<3$ & $3-4$ \\
\hline & Kelembahan (\%) & $\begin{array}{c}<75 \\
74,7-82,2^{8}\end{array}$ & $75-85$ \\
\hline & Ketersedias onssigen (0a) & & \\
\hline & Draingss & $\begin{array}{l}\text { baik, agak } \\
\text { terhambat }\end{array}$ & $\begin{array}{l}\text { agal sepat, } \\
\text { sedang }\end{array}$ \\
\hline & Media perakaran (rs) & & \\
\hline & Telestur & $\begin{array}{l}\text { agak, halus, } \\
\text { sedang liat" }\end{array}$ & $\begin{array}{l}\text { halus, agal } \\
\text { kasar }\end{array}$ \\
\hline & Bahan kasar (\%) & $<15$ & $15-35$ \\
\hline & Kedalaman tanah $(\mathrm{cm})$ & $>75$ & $50-75$ \\
\hline & Retensi hara $(\mathbf{n r})$ & & \\
\hline & KTK liat (cmol) & $>16$ & 16 \\
\hline & Keienuhan basa (\%) & $>35$ & $20-35$ \\
\hline & PH Air & $5,2-8,2$ & $\begin{array}{l}4,8-5,2 \\
8,2-8,4\end{array}$ \\
\hline & C-Qrganils (\%) & $>2$ & $1-2$ \\
\hline & Bahaxa erosi (eh) & & \\
\hline
\end{tabular}

Sumber : Djaenudin et al (2003) dalam Wijanarko (2007*Dinas Pertanian Tanaman Pangan (Wijanarko, 2007)
Tabel 2. Keterangan Kelas Kesesuaian Lahan dar1

\begin{tabular}{|c|l}
\hline $\begin{array}{c}\text { Kelas } \\
\text { Kesesuaian Lahan }\end{array}$ & \multicolumn{1}{c}{ Keterangan } \\
\hline S1 (Sangat Sesuai) & $\begin{array}{l}\text { Lahan tidak memiliki faktor pembatas yang ber } \\
\text { terhadap penggunaan secara berkelanjutan, at } \\
\text { yang bersifat tidak dominan dan tidak akan me } \\
\text { produktifitas Lahan secara nyata }\end{array}$ \\
\hline S2 (Cukup Sesuai) & $\begin{array}{l}\text { Lahan mempunyai faktor pembatas, dan faktor } \\
\text { akan berpengaruh terhadap produktifitasnya, } n \\
\text { tambahan masukan (input). Pembatas tersebut } \\
\text { diatasi oleh petani sendiri }\end{array}$ \\
\hline S3 (Sesuai Marginal) & $\begin{array}{l}\text { Lahan mempunyai faktor pembatas yang domit } \\
\text { pembatas ini akan berpengaruh terhadap prodı } \\
\text { memerlukan tambahan masukan yang lebih ba } \\
\text { Lahan vang tergolong S2. Untuk mengatasi fakt }\end{array}$ \\
\hline
\end{tabular}

Sumber : Permentan Nomor 79 Tahun 2013 tentang Pedoman Kesesuaian Lahan Tanaman Pangan

Penelitian ini meliputi data primer dan data sekunder. Data primer diperoleh dengan melakukan survey langsung ke kecamatan atau desa terpilih sebagai sampel untuk memverifikasi dan memvalidasi data kesesuaian lahan dan produktivitas tanaman ubi Cilembu. Sementara data sekunder berupa data spasial ataupun data tabular diperoleh dari instansi terkait seperti pemerintah daerah kabupaten Sumedang serta berbagai literatur yang digunakan.

Data-data spasial yang digunakan dalam penelitian ini antara lain; peta suhu, curah hujan, lama bulan kering, drainase, tekstur tanah, kedalaman tanah, $\mathrm{pH}$ air, lereng dan genangan. Sedangkan data tabular yang dibutuhkan adalah data luas lahan, produksi dan produktivitas tanaman ubi Cilembu tahun 2015. Data spasial yang telah terkumpul akan diolah dan diproses dengan menggunakan software ArcGIS 9.3. Tahapan dalam penelitian disajikan pada Gambar 1.

\section{Pengolahan Data Spasial}

Pengolahan data meliputi pengolahan data spasial dasar dan tematik, yaitu peta kesesuaian lahan tanaman ubi Cilembu. Peta tematik didapatkan dengan meng-overlay beberapa peta, antara lain peta peta suhu, curah hujan, lama bulan kering, drainase, tekstur tanah, kedalaman tanah, $\mathrm{pH}$ air, lereng dan genangan. Selanjutnya memasukkan kriteria fisik lahan ubi Cilembu ke dalam peta hasil overlay sehingga 
dihasilkan Peta Kesesuaian Lahan tanaman ubi Cilembu dengan klasifikasi kesesuaian lahannya, yaitu Sesuai (S1, S2, S3) dan Tidak Sesuai (N).

\section{Pengolahan Data Tabular}

Pengolahan data luas lahan dan produksi tanaman ubi Cilembu untuk mendapatkan produktivitas tanaman ubi Cilembu. Produktivitas tanaman tersebut kemudian diklasifikasikan menjadi produktivitas tinggi, sedang dan rendah. Selanjutnya klasifikasi produktivitas tersebut dirubah ke dalam bentuk data spasial berdasarkan administrasinya sehingga dihasilkan peta produktivitas tanaman ubi Cilembu.

\section{Keselarasan Kesesuaian Lahan dengan Produktivitas Tanaman}

Pembuatan peta keselarasan dilakukan dengan cara overlay antara peta kesesuaian lahan dengan peta produktivitas yang $d$ berdasarkan pada matriks keselarasan kesesuaian lahan dan produktivitas tanaman ubi Cilembu seperti yang disajikan pada tabel
Tabel 3. Matriks Keselarasan Kesesuaian Lahan dengan Produktivitas Tanaman

\begin{tabular}{|c|c|c|c}
\hline \multirow{2}{*}{$\begin{array}{c}\text { Tingkat } \\
\text { Kesesuaian Lahan }\end{array}$} & \multicolumn{3}{|c}{ Tingkat Produktivitas Tanaman Ubi Cile } \\
\cline { 2 - 4 } & Rendah & Sedang & \\
\hline S1 & Tak Selaras & Selaras & \\
\hline S2 & Tak Selaras & Selaras & \\
\hline S3 & Selaras (-) & Selaras & \\
\hline N & Selaras (-) & Tak Selaras (+) & \\
\hline Keterangan: \\
Selaras
\end{tabular}

Sumber : Sigit, 2006

Survey lapang dilakukan pada daerahdaerah dengan hasil keselarasan yang tak selaras (-) dan tidak selaras. Tak selaras $(+)$ adalah ketika kesesuaian lahannya tidak sesuai namun produktivitasnya tinggi dan tidak selaras adalah ketika tingkat kesesuaian lahannya sesuai namun tingkat produktivitasnya rendah.

\section{Tahap Analisis}

Analisis deksriptif digunakan untuk menganalisa kesesuaian lahan dan produktivitas tanaman ubi Cilembu. 3 .

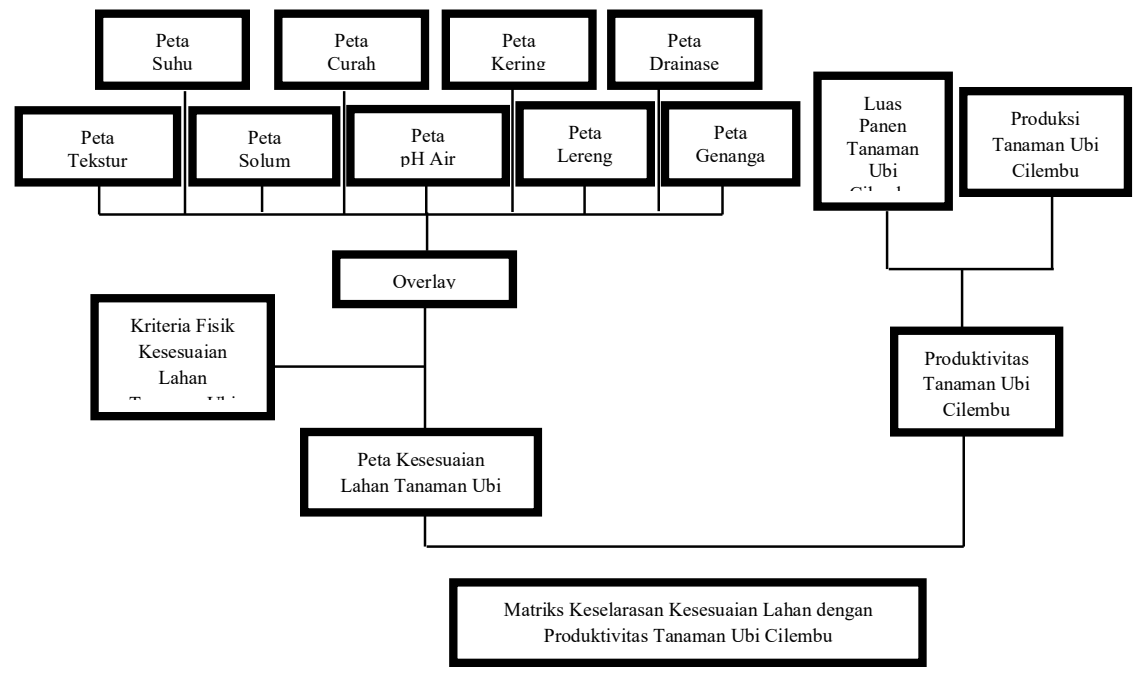

Gambar 1. Alur Kerja Penelitian

\section{HASIL DAN PEMBAHASAN}

\section{Kesesuaian Lahan Tanaman}

Kesesuaian lahan tanaman ubi Cilembu didasarkan atas karakteristik fisik lahan dari daerah asal tanaman tersebut. Berdasarkan penelitian terdahulu atau studi litaratur serta survey lapang ke daerah asal tanaman ubi Cilembu maka terdapat beberapa persyaratan fisik optimum untuk penanaman tanaman ini. Persyaratan fisik optimum tersebut 
membentuk karakteristik lahan yang sangat sesuai (S1) untuk ditanami. Sedangkan persyaratan fisik yang masih dapat ditoleransi untuk penanaman masuk kedalam klasifikasi cukup sesuai (S2) dan sesuai marginal (S3). Hal tersebut terkait dengan berbagai keterbatasan fisik yang dapat mengganggu proses penanaman. Kesesuaian lahan yang tidak sesuai $(\mathrm{N})$ meliputi lahan dengan faktor pembatas yang sangat dominan sehingga sulit untuk diatasi.

Diantara persyaratan fisik yang optimum untuk penanaman yang diperoleh dari survei lapang adalah perbukitan dengan ketinggian di atas $900 \mathrm{~m}$ dpl. Adapun curah hujan optimal untuk penanaman sekitar $750-$ $2.000 \mathrm{~mm}$ per tahun dengan suhu $16-34{ }^{\circ} \mathrm{C}$ (optimum $27^{\circ}$ ) dan kelembaban udara berkisar antara 50 sampai 80 persen serta lama penyinaran matahari selama 9 - 12 jam. Pertumbuhan dan produksi yang optimal untuk tanaman ini tercapai pada musim kering (kemarau) tetapi dengan syarat kebutuhan air tercukupi. Tanah yang baik untuk ubi Cilembu adalah tanah latosol coklat yang banyak mengandung bahan organik dengan aerasi dan drainase yang baik. Umumnya lahan sawah bekas tanaman padi sangat baik untuk tanaman ini. Kondisi lahan optimum adalah lahan yang tidak becek atau tidak tergenang air serta memiliki $\mathrm{pH}$ berkisar antara 5,5 sampai 7,5.

Lokasi yang paling optimal untuk ditanami adalah di daerah asal ubi Cilembu, tepatnya di desa Cilembu, kecamatan Pamulihan. Lokasi lainnya adalah di sekitar desa Cilembu yang meliputi 33 desa/kelurahan lain yang tersebar di 4 kecamatan, yaitu Pamulihan, Rancakalong, Tanjungsari dan Sukasari. Persebaran kesesuaian lahan tanaman Ubi Cilembu di kabupaten Sumedang dapat dilihat pada Gambar 2.

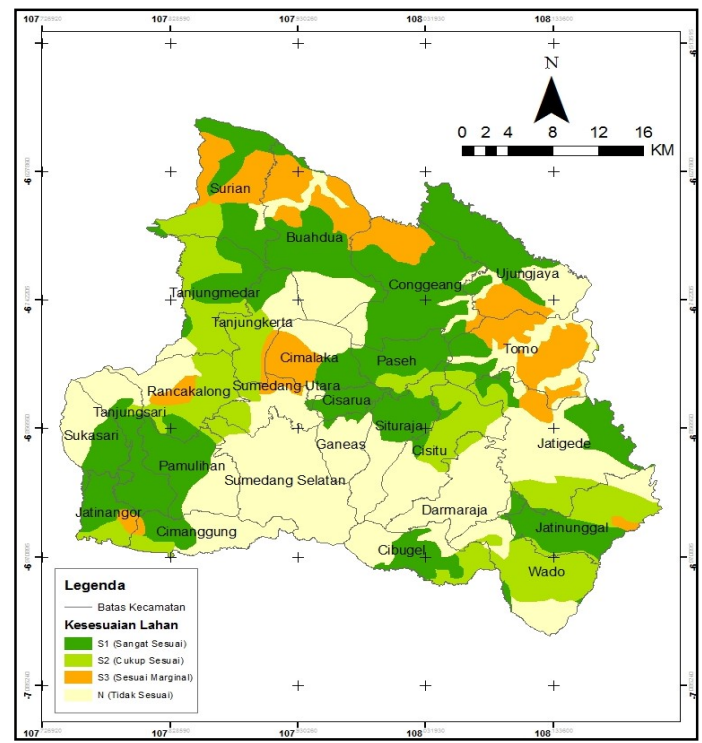

Gambar 2. Peta kesesuaian lahan tanaman ubi Cilembu di kab. Sumedang

Kesesuaian lahan sangat sesuai tersebar di beberapa kecamatan yang meliputi kecamatan Pamulihan, Tanjungsari, Sukasari, Cimanggung, Conggenag, Buahdua, Paseh, Jatinunggal dan Cibugel. Kecamatan Pamulihan merupakan tempat dimana ubi Cilembu berasal, tepatnya di desa Cilembu. Tabel 4 berikut merupakan luasan kesesuaian lahan tanaman ubi Cilembu di kabupaten Sumedang dengan berbagai kelas kesesuaian lahan.

Tabel 4. Luasan Kesesuaian Lahan Tanaman Ubi Cilembu

\begin{tabular}{|l|c|}
\hline $\begin{array}{c}\text { Kesesuaian } \\
\text { Lahan }\end{array}$ & $\begin{array}{c}\text { Luasan } \\
\text { (Hektar) }\end{array}$ \\
\hline S1 (Sangat Sesuai) & $52.800,53$ \\
\hline S2 (Cukup Sesuai) & $27.277,98$ \\
\hline
\end{tabular}

Sumber : Pengolahan data, 2019

\section{Produktivitas Tanaman Ubi Cilembu}

Produktivitas tanaman ubi Cilembu merupakan hasil perhitungan dari produksi 
tanaman dengan luasan penanamannya. Gambar 3 menunjukkan sebaran produktivitas tanaman ubi di seluruh kecamatan yang ada di kabupaten Sumedang.

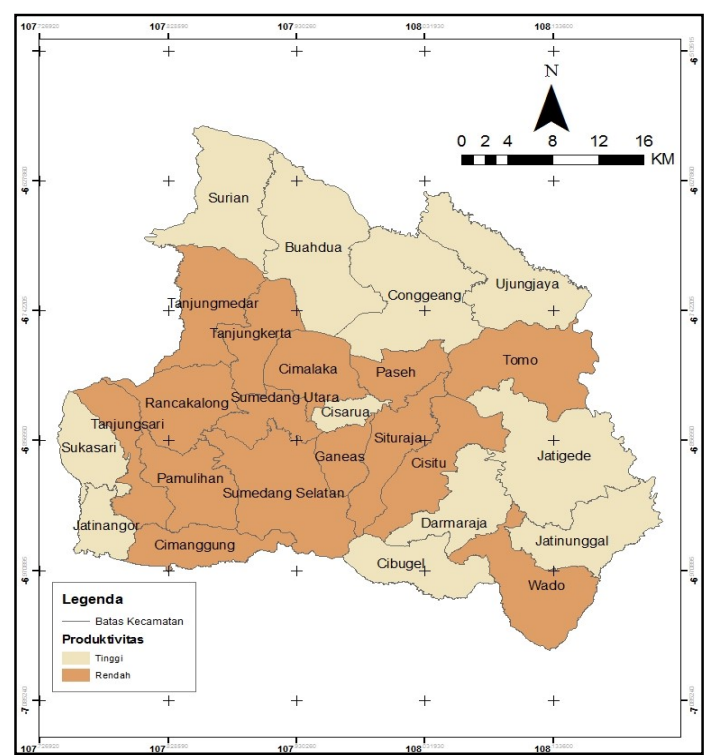

Gambar 3. Peta produktivitas ubi Cilembu di Kabupaten Sumedang

Produktivitas tinggi terdapat di 15 kecamatan dengan rentang nilai 81,39-162,76 kwintal per hektar, terletak di bagian barat kab. Sumedang. Kecamatan tersebut meliputi Cimalaka, Cimanggung, Cisitu, Ganeas, Pamulihan, Paseh, Rancakalong, Situraja, Sumedang Utara, Sumedang Selatan, Tanjungkerta, Tanjungmedar, Tanjungsari, Tomo dan Wado. Sedangkan kecamatan yang memiliki produktivitas tinggi khusus untuk tanaman ubi Cilembu berada di 4 kecamatan, yaitu Pamulihan, Rancakalong, Tanjungsari, Sukasari. Sementara di kecamatan lain merupakan ubi varian lain. Sebaliknya, produktivitas rendah terdapat di 11 kecamatan lainnya di kabupaten Sumedang dan bahkan beberapa kecamatan sama sekali bukan merupakan penghasil ubi, seperti kecamatan Buah dua, Cibugel, Cisarua, Conggeang, Jatigede dan Ujungjaya.

Keselarasan Kesesuaian Lahan dengan Produktivitas Tanaman Ubi Cilembu
Produksi tanaman ubi Cilembu pada suatu lahan terpengaruh oleh faktor fisik dan non fisik. Apabila kedua faktor di atas seimbang, maka dikatakan memiliki hubungan yang selaras; sebaliknya, jika salah satu faktor berada pada kondisi yang tidak baik, maka dikatakan hubungannya tidak selaras. Hubungan keselarasan antara kesesuaian lahan dengan produktivitas tanaman ubi Cilembu dinyatakan dalam beberapa bentuk hubungan, yaitu : selaras, selaras (-), tak selaras (+) dan tak selaras. Hubungan yang selaras berarti daya dukung terhadap pertanian tanaman ubi Cilembu relatif baik, sedangkan hubungan selaras (-) berarti daya dukung pertanian tanaman ubi Cilembu jelek. Tak selaras $(+)$ diartikan bahwa upaya manusia relatif baik dalam mengatasi keterbatasan lahan, sedangkan tak selaras berarti bahwa lahan memerlukan pengelolaan lebih intensif.

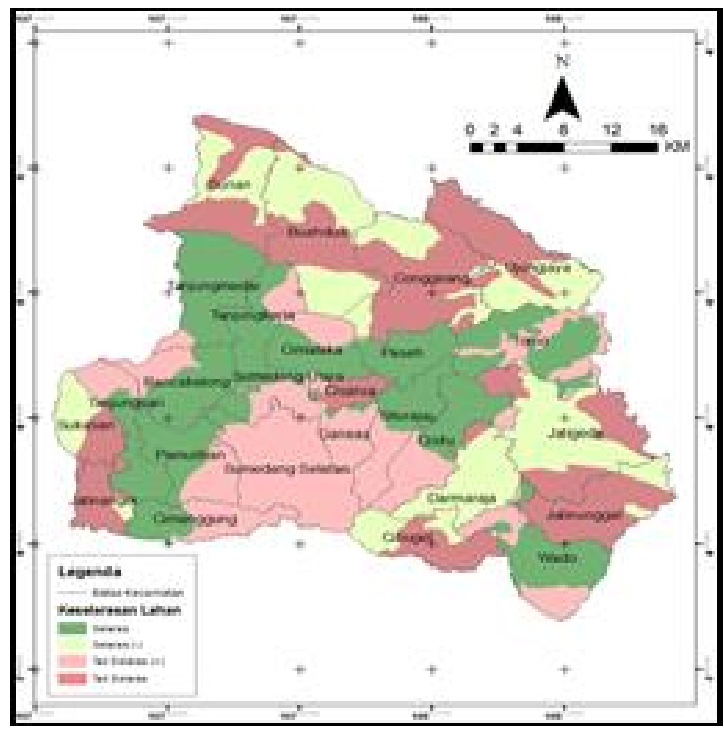

Gambar 3. Peta produktivitas ubi Cilembu di Kabupaten Sumedang

Penggabungan kedua data sebagaimana tersebut secara relatif memudahkan inventarisasi data mengenai baik tidaknya daya dukung lahan terhadap usaha pertanian tanaman ubi Cilembu, serta baik tidaknya upaya manusia dalam mengelola lahan 
pertanian. Adapun dalam tabel 5 disajikan luasan wilayah-wilayah tiap-tiap status keselarasan di daerah penelitian.

Tabel 5. Keselarasan antara kesesuaian lahan dengan produktivitas ubi Cilembu

\begin{tabular}{|l|l}
\hline \multicolumn{1}{|c|}{ Hubungan Keselarasan } & Luasan ( \\
\hline Selaras & \\
\hline Selaras (-) & \\
\hline
\end{tabular}

Sumber : pengolahan data, 2019

\section{Wilayah Selaras}

Sekitar 29\% wilayah kabupaten Sumedang memiliki produktivitas tanaman ubi Cilembu yang sesuai dengan kesesuaian lahan. Faktor fisik dan non fisik sangat mendukung usaha pertanian tanaman Ubi Cilembu. Wilayah dengan status ini memiliki daya dukung yang relatif baik kaitannya dengan usaha pertanian tanaman ubi Cilembu. Upaya pengelolaan lebih ditekankan untuk menjaga daya dukung sehingga produktivitasnya tetap terjaga (tidak menurun). Wilayah ini berada di kecamatan Rancakalong, Tanjungsari, Pamulihan, Tanjungmedar, Tomo, Wado, dan sebagainya.

\section{Wilayah Selaras (-)}

Kurang lebih 21,82\% wilayah kabupaten Sumedang secara nyata tidak baik untuk usaha pertanian tanaman ubi Cilembu. Keselarasan "selaras (-)" menunjukkan bahwa wilayah dengan status tersebut memiliki daya dukung lahan yang relatif buruk untuk tanaman ubi Cilembu. Asumsi logis yang digunakan bahwa lahan dengan kesesuaian 'kurang sesuai' akan memiliki tingkat produktivitas yang 'rendah'. Wilayah dengan status keselarasan ini tidak memberi daya dukung yang baik terhadap usaha pertanian tanaman ubi Cilembu, maka upaya pengelolaan sebaiknya lebih ditekankan pada penanaman tanaman lainnya. Wilayah ini meliputi kecamatan Buahdua, Jatigede, Darmaraja, Conggeang, Surian dan jungjaya.

\section{Wilayah Tak Selaras $(+)$}

Wilayah ini menggambarkan bahwa lahan pertanian tanaman ubi Cilembu telah dikelola dan diupayakan oleh manusia secara baik, sehingga walaupun kondisi fisik lahannya tidak secara nyata mendukung usaha pertanian, namun produktivitasnya baik. Upaya pengelolaan sebaiknya ditekankan pada upaya mempertahankan daya dukung wilayah, sehingga produktivitas tanaman Ubi Cilembu tetap terjaga. Sekitar $26,33 \%$ wilayah kabupaten Sumedang masuk ke dalam status hubungan keselarasan ini yang meliputi kecamatan-kecamatan di bagian selatan, yaitu Sumedang Selatan, Cimanggung, Ganeas, Situraja, Cisitu dan Pamulihan.

\section{Wilayah Tak Selaras}

Wilayah "tak selaras" menunjukkan bahwa lahan dengan status tersebut kurang mendapat pengelolaan yang baik. Status keselarasan ini mengindikasikan adanya permasalahan wilayah terkait dengan kesungguhan manusia atau penduduk dalam pengusahaan lahan pertanian tanaman ubi Cilembu. Wilayah ini merupakan wilayah yang relatif potensial untuk pengusahaan, namun karena kurang optimalnya manusia atau penduduk dalam pengusahaannya mengakibatkan tingkat produktivitasnya tidak sebaik kesesuaian lahannya. Oleh karena itu wilayah ini sebaiknya menjadi target prioritas perhatian dalam pengelolaan. Kurang lebih 22,13\% wilayah kabupaten Sumedang pengusahaan pertanian tanaman ubi Cilembu belum dilakukan secara optimal. Wilayah ini meliputi kecamatan Sukasari, Jatinunggal, dan lain-lain. Upaya pengelolaan pada wilayah ini lebih ditekankan kepada pengembangan teknis seperti penerapan teknologi yang menjurus kepada peningkatan produktivitas tanaman ubi Cilembu. 


\section{KESIMPULAN}

Penyusunan kesesuaian lahan merupakan salah satu alternatif untuk mengatasi permasalahan. Dari hasil penelitian, disebutkan bahwa sebanyak 33\% kabupaten Sumedang sangat sesuai untuk ditanami ubi Cilembu. Hal tersebut mengacu kepada persyaratan fisik tanaman ubi Cilembu untuk tumbuh secara optimal. Dalam upaya menyusun solusi, maka hubungan antara kesesuaian lahan ubi Cilembu dengan produktivitas tanaman tersebut diidentifikasi sehingga menghasilkan wilayah-wilayah yang secara fisik maupun non fisik dapat digunakan untuk mengevaluasi keefektifan upaya penanaman ubi Cilembu di kabupaten Sumedang. Wilayah yang perlu diperhatikan adalah wilayah yang secara fisik sesuai untuk ditanami ubi Cilembu namun faktor manusia tidak mendukung. Wilayah yang secara fisik tidak sesuai untuk ditanami ubi Cilembu namun produktivitasnya tinggi juga harus menjadi perhatian.

\section{DAFTAR PUSTAKA}

Badan Pusat Statistik. 2014. Jawa Barat Dalam Angka.

Haryati, dkk. Petunjuk Teknis Budidaya Ubi Cilembu Organik. Bandung Barat: BPTP Jawa Barat.
Permentan. 2013. Peraturan Menteri Pertanian Nomor 73 Tahun 2013 tentang Pedoman Kesesuaian Lahan pada Komoditas Tanaman Pangan.

Ruwanti, S. 2010. Optimasi Kadar ß-Karoten Pada Proses Pembuatan Tepung Ubi Jalar Oranye (Ipomoea batatas L) Dengan Menggunakan Response Surface Methodology (RSM). [Skripsi]. Surakarta: Universitas Sebelas Maret.

Sigit, A. Anggoro. Analisis Keselarasan Antara Kondisi Lahan dan Produktivitas Tanaman Pangan dengan Teknologi SIG di Kabupaten Klaten Jawa Tengah. J. Penelitian Sains \& Teknologi, 7 (2), Oktober 2006: hal 150 -159 .

Solihin, Moh. Amir. Potensi Lahan Pengembangan Ubi Cilembu di Kabupaten Sumedang. J. Soilrens, 8 (15), Juli 2007: hal 765-774.

Solihin, E. Ubi Cilembu di Ekspor ke Korea [serial online] Mei 2014 [sitasi 08 September 2019] : Tersedia di : https://www.antaranews.com/berita/434 351/ubi-cilembu-diekspor-ke-korea

Wijanarko, Yulius. 2007. Kesesuaian Lahan Untuk Tanaman Ubi Cilembu di Kecamatan Jatisrono Kabupaten Wonogiri. [Skripsi]. Surakarta: Universitas Sebelas Maret. 